Research Paper

\title{
Similarities and differences between HIV and SARS-CoV-2
}

Francisco Illanes-Álvarez*, Denisse Márquez-Ruiz*, Mercedes Márquez-Coello, Sara Cuesta-Sancho ${ }^{\bowtie}$ and José Antonio Girón-González ${ }^{\bowtie}$

Unidad de Enfermedades Infecciosas, Servicio de Medicina Interna, Hospital Universitario Puerta del Mar, Facultad de Medicina, Universidad de Cádiz, Cádiz, Spain. Instituto de Investigación e Innovación en Ciencias Biomédicas de la Provincia de Cádiz (INiBICA).

*These authors contributed equally to this work.

$\triangle$ Corresponding authors: Sara Cuesta-Sancho \& José Antonio Girón-González contributed equally to this work. Sara Cuesta-Sancho, Unidad de Investigación, Universitario Puerta del Mar, Avda Ana de Viya 21, 11009 Cádiz, Spain. E-mail: sara.cuesta@inibica.es; José A. Girón-González, Servicio de Medicina Interna, Hospital Universitario Puerta del Mar, Avda Ana de Viya 21, 11009 Cádiz, Spain. E-mail: joseantonio.giron@uca.es.

(C) The author(s). This is an open access article distributed under the terms of the Creative Commons Attribution License (https://creativecommons.org/licenses/by/4.0/). See http://ivyspring.com/terms for full terms and conditions.

Received: 2020.06.30; Accepted: 2020.11.17; Published: 2021.01.01

\begin{abstract}
In the last 50 years we have experienced two big pandemics, the HIV pandemic and the pandemic caused by SARS-CoV-2.

Both pandemics are caused by RNA viruses and have reached us from animals. These two viruses are different in the transmission mode and in the symptoms they generate. However, they have important similarities: the fear in the population, increase in proinflammatory cytokines that generate intestinal microbiota modifications or NETosis production by polymorphonuclear neutrophils, among others. They have been implicated in the clinical, prognostic and therapeutic attitudes.
\end{abstract}

Key words: COVID-19; AIDS; pandemics; HIV; SARS-CoV-2

\section{Introduction}

In the last 50 years, we have experienced two pandemics, the human immunodeficiency virus (HIV) and the severe acute respiratory syndrome coronavirus 2 (SARS-CoV-2) infections.

Both are caused by natural viruses that have reached us from animals [1-3]. Although these two viruses are different in the transmission mode and in the symptoms they generate, they have important similarities between them.

HIV infection was discovered in the 80s (1981), when the first cases were known in young adults in California. It is believed that HIV spread to humans through direct contact with the infected blood of chimpanzees by hunting them for their meat. They were affected by severe pneumonia caused by Pneumocystis jiroveci or with Kaposi's sarcoma. The transmission mechanism was sexual contact, drugs injection, blood transfusions and mother-to-child. A social stigma was generated. HIV spread rapidly throughout the world and the death rate was almost $100 \%[4]$.

The first isolation of HIV-1 was achieved in 1983 by Barré-Sinoussi and collaborators at the Pasteur
Institute in Paris [5]. Since then, there has been a great advance in the knowledge of HIV, being one of the best-characterized known viruses, and a large amount of information has been accumulated about its biology, transmission and pathogenesis.

Although there is no cure for HIV infection, effective antiretroviral therapy (ARTs) can control the virus and help prevent transmission to other people. At the end of 2018, approximately $79 \%$ of people living with HIV knew their status, $62 \%$ were receiving antiretroviral therapy (ART) and 53\% had achieved suppression of the HIV with no risk of infecting others. Between 2000 and 2018, new HIV infections fell by $37 \%$ and HIV-related deaths fell by $45 \%$, with 13.6 million lives saved due to ART [4].

In the case of SARS-CoV-2, the first cases appeared in December 2019 in Wuhan, in the Chinese province of Hubei. There were 41 cases of people with pneumonia, $66 \%$ of which had direct exposure in a seafood market where all kinds of meat and fish were sold, so it is thought that the origin might be there. The first news were released in January 2020 when the complete viral genome sequence was published [6], 
showing that it was a new coronavirus belonging to the same group as the coronavirus related to the severe acute respiratory syndrome (SARS-CoV) causing the outbreak from SARS 2003 [7-9].

On March $11^{\text {th }}$, when globally confirmed cases exceeded 118,000 and the number of deaths were 4,291, the WHO characterized the SARS-CoV-2 infection as a pandemic named COronaVIrus Disease 19 (COVID-19) [4]. From that day on, most countries in the world have suffered the infection and it is not yet controlled.

\section{Material and methods}

This review provides a comprehensive overview of HIV and SARS-CoV-2 viruses similarities and differences. The data source was PubMed and the search terms and strategy were focused on the definition, epidemiology, transmission mechanism, symptomatology and finally treatment and vaccine development. The results are summarized in a narrative manner.

\section{Results and Discussion}

\section{Human Immunodeficiency Virus (HIV)}

\section{Definition}

HIV is a virus that belongs to the genus Lentivirus, subfamily Orthoretrovirinae, family Retroviridae. Two types have been identified, HIV-1 and HIV-2 [10].

The HIV-1 virion is a spherical particle, with around $100 \mathrm{~nm}$ of diameter, that contains two copies of single-stranded RNA together with the enzymatic machinery (reverse transcriptase and integrase) implicated in its transformation from RNA to DNA in the cytoplasm of the host cell and the subsequent integration of this material into the cell genome (proviral DNA) [11]. The HIV-1 envelope is formed by viral gp41 and gp120 envelope glycoproteins, with ability to bind to the CD4 surface protein, present in certain cells, including $\mathrm{T}$ lymphocytes and mononuclear phagocytic cells. This union produces a conformational change in the viral glycoprotein that allows its subsequent interaction with one of the chemokine receptors (CCR5 and CXCR4), which act as co-receptors for the virus, allowing its entry into the cell. Once inside, it will use the enzyme reverse transcriptase to convert its RNA into DNA, which will be later transported to the nucleus and integrated into the cellular DNA. As mentioned above, HIV-1 infects immune system key cells, mainly CD4+ $\mathrm{T}$ helper lymphocytes. Consequently, there is a depression of the immune system. If this depression becomes chronic, the patient progresses to AIDS [12].

\section{HIV epidemiology}

According to UNAIDS (United Nations on HIV/AIDS) in its most recent update in 2018, there are 37.9 million estimated individuals living with HIV all over the world. There are estimations that predict 1.8 million of new HIV-1 infections each year. The results show that new infections (of all ages) decreased from a peak of 3.4 million in 1996 to 1.8 million in 2017 [13]. From the start of the pandemic until 2018, 32 million people died from AIDS-related illnesses [13].

\section{HIV transmission mechanism}

There are three transmission mechanisms of HIV-1 infection: sexual, parenteral and vertical [14]. HIV is found in blood, pre-seminal fluid, semen, vaginal fluids, and breast milk, and is transmitted through direct contact of these fluids with the mucosa or bloodstream of another person.

According to the data available, in Spain, the most frequent transmission mechanism nowadays is sexual, mainly from men who have sexual relations with other men (approximately $54.3 \%$ of all new cases), followed by heterosexual transmission (28\%) and injecting drug use (less than 3.1\%) [12].

\section{HIV symptomatology}

The symptoms generated by HIV infection begin to appear between 2 and 6 weeks after contact with the virus and can be divided into early infection (within the first two months after infection) or chronic. During the early or acute phase of infection, infected people present fever, headache, muscle pain, rashes, sore throat and mouth sores, and swollen lymph nodes. These symptoms can be so mild that are almost not noticed [5].

In the phase of chronic infection, the virus continues spreading and destroying immune cells, causing immunosuppression. Usually, if it is not treated, HIV turns into AIDS in an average of 10 years. When AIDS occurs, the immune system is already severely damaged, opportunistic infections, neurodegenerative diseases and cancers occur in infected individuals [5].

\section{Treatment and vaccine development}

After the initial discovery of some drugs that had shown high toxicity and scarce benefit (zidovudine, didanosine, zalcitabine), in 1995 the discovery of a combination therapy, which initially included antiprotease drugs (indinavir, saquinavir) was such a change that it was possible to significantly reduce mortality. Antiretroviral therapies (ART) have tranformed HIV infection into a chronic disease [12]. After 2008, the emergence of new drugs, including 
integrase inhibitors, has led to significantly less toxicity and excellent tolerance [15].

However, HIV persists in the body due to the early establishment of reservoirs, which cannot be eliminated with any of the current antiretroviral regimens [16]. Reservoirs are defined as anatomical sites or cells in which HIV infection is persistent and stable allowing competent viruses to replicate under permissive conditions.

Studies searching for vaccines have not been successful yet.

\section{SARS-CoV-2}

\section{Definition}

SARS-CoV-2 is a $\beta$-coronavirus, from the sub-genus Sarbecovirus, subfamily Orthocoronavirinae. The size of the SARS-CoV-2 virion is approximately 50 to $200 \mathrm{~nm}$ of diameter, and its genome is single-stranded positive-sense RNA. The complete genome of the SARS-CoV-2 virus has been sequenced, it has $29.2 \mathrm{~kb}$ [9], with a variable number between 6 and 20 Open Reading Frames (ORFs) [17]. Two thirds of the viral RNA are found in the first ORF $(\mathrm{ORF} 1 \mathrm{a} / \mathrm{b})$, which is translated into two structural proteins (pp1a and pp1ab) and 16 non-structural proteins (NSP), whereas the other ORFs encode accessory and structural proteins. The rest of the virus genome encodes four essential structural proteins, namely spike glycoprotein (S), small envelope (E), matrix (M) and nucleocapside (N) [18]. Additional accessory proteins interfere with the immune response of the host.

Zhou et al. [3] confirmed that SARS-CoV-2 uses the ACE2 receptor to enter into the cells, just as SARS-CoV-1 does. This receptor is expressed in the lung, heart, blood vessels, intestine and kidneys [19]. The coronavirus membrane glycoprotein $S$ is the one that binds to the ACE2 receptor on the surface of human cells [20]. The $S$ glycoprotein has two subunits, namely S1 and S2 [21]. S1 determines the virus-host ratio and cell tropism with the key fusion domain, which is RBD, while S2 mediates the fusion of the virus cell membrane by two tandem domains: heptad repeats 1 (HR1) [22] and 2 (HR2) [23]. After the fusion virus-cell occurs, the virus genome is released into the cytoplasm and the RNA translates two polyproteins, pp1a and pp1ab [24], which encode non-structural proteins and form replication-transcription complexes (RTCs) in double-membrane vesicles [25]. RTCs replicate and synthesize sets of subgenomic RNAs [26] that encode for structural and accessory proteins. By using cellular endoplasmic reticulum and the Golgi, newly formed RNAs, nucleocapsid proteins, and envelope proteins bind and form new viral particles [27]. Finally, the vesicles containing the virions fuse with the cell membrane and the virus goes out to infect new cells. The difference with HIV is that SARS-CoV-2 does not integrate in the host DNA. The generation of antibodies 15 days after infection is $100 \%$, both in mild and severe cases [28-32].

\section{SARS-CoV-2 epidemiology}

The situation of SARS-CoV-2 infection today, November 7th 2020, according to the $\mathrm{WHO}$, is as follows: 48,534,508 confirmed cases worldwide with $1,231,017$ deaths since the start of the pandemic in December 2019. Currently, the continent with most cases is America with 21,168,405 confirmed cases and 650,705 deaths. In Europe, the confirmed cases are 12,490,012 with 303,707 deaths [4].

The mortality rate of SARS-CoV-2 (3.8\%) is lower than that of SARS-CoV-1 or MERS-CoV (Middle East Respiratory Syndrome Coronavirus), whose rates were $10 \%$ and $37.1 \%$ respectively, but the number of cases of infection is 10 times higher. This is due to the fact that SARS-CoV-2 can be transmitted from people with no symptoms or with mild infections. These characteristics can explain the sudden pandemic spread of the virus [33]. In general the mortality rate is $5 \%$ [34], being $49 \%$ in critical cases $[35,36]$.

\section{SARS-CoV-2 transmission mechanism}

The virus is transmitted through the air, mainly due to small drops of saliva from infected people by coughing or sneezing that can reach two meters [37]. The transmission is also produced by direct contact with these secretions or by objects contaminated by them [4].

\section{SARS-CoV-2 symptomatology}

The symptoms generated by SARS-CoV-2 begin to appear between 2 and 14 days after the contact with the virus. The most common symptoms include fever, cough, and dyspnea. Diarrhea and abdominal pain are also frequent. Although most cases have mild symptoms, in the most severe cases, the infection can cause pneumonia, severe difficulty breathing, kidney failure, and even death [38, 39].

\section{Treatment and vaccine development}

COVID-19 treatment initially included drugs previously used in HIV treatment, such as lopinavir; subsequent studies demonstrated its lack of efficacy [40]. Moreover, as in the case of HIV infection, the first antiviral used (Remdesivir) has shown very limited efficacy [41, 42]. Apart from corticosteroids to decrease cytokine storm [43], there are no other useful drugs against SARS-CoV-2 infection.

Many trials are being done to find a vaccine against SARS-CoV-2 [44], some of them with encouraging results in phase II. 


\section{Differences between HIV-1 and SARS-CoV-2}

Table 1 shows a summary of the main differences described between both viruses.

Table 1. Differences between HIV and SARS-CoV-2

\begin{tabular}{|c|c|c|}
\hline & HIV & SARS-CoV-2 \\
\hline Phylogenetically & Lentivirus & $\beta$-coronavirus \\
\hline $\begin{array}{l}\text { Transmission } \\
\text { mechanism }\end{array}$ & $\begin{array}{l}\text { Sexual, parenteral and vertical } \\
\text { direct contact. }\end{array}$ & $\begin{array}{l}\text { Air by small drops of } \\
\text { saliva. }\end{array}$ \\
\hline Targets & $\begin{array}{l}\text { CD4 surface protein expressed } \\
\text { in CD4+ T helper lymphocytes, } \\
\text { macrophages, and dendritic } \\
\text { cells. }\end{array}$ & $\begin{array}{l}\text { ACE2 receptor expressed } \\
\text { in lung, heart, blood } \\
\text { vessels, intestine, and } \\
\text { kidney. }\end{array}$ \\
\hline Symptoms & $\begin{array}{l}\text { In early infection: flu-like } \\
\text { and/or mononucleosis-like } \\
\text { symptoms; in chronic infection: } \\
\text { opportunistic entities; usually, if } \\
\text { it is not treated, HIV turns into } \\
\text { AIDS in about } 10 \text { years. }\end{array}$ & $\begin{array}{l}\text { Difficulty breathing and } \\
\text { fever. In the most severe } \\
\text { cases, the infection can } \\
\text { cause pneumonia, severe } \\
\text { difficulty breathing, } \\
\text { kidney failure, and even } \\
\text { death. }\end{array}$ \\
\hline $\begin{array}{l}\text { Days from } \\
\text { infection with } \\
\text { symptoms }\end{array}$ & $\begin{array}{l}\text { Between } 2 \text { and } 6 \text { weeks after } \\
\text { contact with the virus. }\end{array}$ & $\begin{array}{l}\text { Between } 2 \text { and } 14 \text { days } \\
\text { after contact with the } \\
\text { virus. }\end{array}$ \\
\hline $\begin{array}{l}\text { Death } \\
\text { percentage } \\
\text { without } \\
\text { treatment }\end{array}$ & $\geq 95 \%$ & $1-4 \%$ \\
\hline
\end{tabular}

\section{Similarities between both viruses}

Even though it may seem that these two viruses induced diseases are not very similar among them, they have some important points in common:

(a) Fear in the population. HIV can affect anyone, independently of their social status, race, gender, etc. This can affect people psychologically, making them feel fear, stress or anxiety. Apart from those factors, in COVID-19, there are others that can make people feel this - the virus is new, there are not known effective antivirals, the disease is more contagious than expected, it can even severely affect young individuals with no previous pathologies, respiratory failure forces hospitalization for many days... In addition, the panic is even increased by the presence of the Internet, over-information, spreading of unfounded rumors, and hyper connectivity in our lives nowadays.

(b) Existence of animal reservoirs. The existence of natural animal reservoirs is another point in common, although they are found in different animals, being non-human primates in the case of $\mathrm{HIV}$, and bats in the case of SARS-CoV-2.

(c) Increased synthesis of proinflammatory cytokines. Both viruses generate an increase in the production of cytokine, and this is linked to the viral load in the case of SARS-CoV-2. These cytokines are related with secondary complications in infected people.

It is well known that in HIV infection, the cytokine release is a chronic mechanism that generates prolonged inflammation. Sustained inflammatory status has been related with increased intestinal permeability and bacterial translocation, detected in HIV-infected patients. Intestinal permeability, bacterial translocation or systemic inflammation cannot be reversed with antiretroviral therapies [45]. Residual viral replication and other co-infections also contribute to prolonged inflammatory status [45]. Serum levels of the proinflammatory interleukin 6 has been independently associated to morbidity (cardiovascular disease, cancer, etc.) and mortality in patients with controlled HIV replication [46].

Regarding COVID-19, the cytokine secretion is an acute response and is implicated in clinical manifestations. Proinflammatory cytokines and chemokines attract more inflammatory cells to migrate from the blood, inducing an amplification of the deleterious response; in fact, a substantial part of the therapy is aimed at blocking pro-inflammatory cytokines [47]. Cytokine storm is implicated in the acute respiratory distress syndrome or multiple-organ dysfunction. Increased markers of systemic inflammation are prognostic variables in COVID-19 [48].

(d) Modifications of the intestinal microbiota. It has been proved that patients infected with SARS-CoV-2 who develop cardiac complications have higher levels of intestinal permeability and activation of inflammasomes, suggesting a heart-intestine axis in COVID-19 [49]. In fact, one of the vaccines being developed is a genetically modified probiotic with a plasmid that contains the DNA of the SARS-CoV-2 protein S (NCT04334980).

HIV infection has an unfavorable effect on the interaction between the commensal microbiota and the immune system [50]. Microbiota modifications (increase in pro-inflammatory bacteria and a reduction in those that promote homeostasis) have been detected in HIV infected people with pathogenic consequences on bacterial translocation (see above) and immune responses [51-61]. It is important to mention that elite controllers have microbiomes more similar to those of healthy individuals than other groups of HIV-infected patients [62], and they also show lower levels of immune activation and HIV reservoirs [63].

(e) Neutrophil extracellular traps (NETs) formation. The two viruses share a mechanism known as NETosis. This is a neutrophil death mechanism in which neutrophils release nets of chromatin fibers into the extracellular space. Those nets contain histones, microbicidal peptides or oxidizing enzymes [64]. NETs are very adherent and capture extracellular microbes, such as some bacteria, fungi and virus, 
stimulating its removal [64-66]. Acute NETosis against infectious agents is an efficient defense mechanism that avoids collateral tissue damage, concentrating the antimicrobial action and reducing the toxicity attributable to the proteases. However, a chronic or acute aberrant NETosis may contribute to the pathology [67]. In HIV infection, NETosis has been suggested to be involved in the atherosclerosis development [66]. In COVID-19, the virus-induced NETs can circulate in an uncontrolled way, giving rise to an extreme systemic response of the body, increasing the concentrations of cytokines, chemokines and increasing inflammation. In addition to promoting the cytokine storm, NETs in COVID-19 patients are also responsible for the thrombotic complications they present, as is the case in HIV patients [68].

\section{Conclusion}

As a conclusion, we would like to point that although at first sight these viruses do not resemble each other, the molecular mechanisms used are common: the increased of pro-inflammatory cytokine synthesis, the modifications in intestinal microbiota, the NETs formation. Basic science has been trying to understand these mechanisms for years and the greater the knowledge, the lesser the damage to the population in this pandemic and in the future.

\section{Acknowledgements}

\section{Financial support}

This work was supported by the Instituto de Salud Carlos III, Acción Estratégica en Salud 2014 (No PI19/01361), Spain. Co-financed by FEDER (Fondo Europeo de Desarrollo Regional).

\section{Competing Interests}

The authors have declared that no competing interest exists.

\section{References}

1. Sharp PM, Hahn BH. Origins of HIV and the AIDS pandemic. Cold Spring Harb Perspect Med. 2011; 1(1).

2. Zhang YZ, Holmes EC. A Genomic Perspective on the Origin and Emergence of SARS-CoV-2. Cell. 2020; 181(2):223-7.

3. Zhou P, Yang X Lou, Wang XG, Hu B, Zhang L, Zhang W, et al. A pneumonia outbreak associated with a new coronavirus of probable bat origin. Nature. 2020; 579(7798):270-3.

4. [Internet] World Health Organization (WHO). https://www.who.int/. 2020 (accessed November 2020).

5. Vaillant AAJ, Gulick PG. HIV Disease, in: StatPearls [Internet], StatPearls Publishing. 2019.

6. Wu A, Peng $Y$, Huang B, Ding X, Wang X, Niu P, et al. Genome Composition and Divergence of the Novel Coronavirus (2019-nCoV) Originating in China. Cell Host Microbe. 2020; 27(3):325-8.

7. Lu R, Zhao X, Li J, Niu P, Yang B, Wu H, et al. Genomic characterisation and epidemiology of 2019 novel coronavirus: implications for virus origins and receptor binding. Lancet. 2020; 395(10224):565-74.

8. Zhu N, Zhang D, Wang W, Li X, Yang B, Song J, et al. A Novel Coronavirus from Patients with Pneumonia in China, 2019. N Engl J Med. 2020; 382(8):727-33.
9. Wu F, Zhao S, Yu B, Chen YM, Wang W, Song ZG, et al. A new coronavirus associated with human respiratory disease in China. Nature. 2020; 579(7798):265-9.

10. Abbas AK, Lichtman AH, Pillai S. Cellular and Molecular Immunology, ninth ed., Elsevier Health Sciences, Philadelphia, 2017.

11. Rein A. RNA Packaging in HIV. Trends Microbiol. 2019; 27(8):715-23.

12. Towers GJ, Noursadeghi M. Interactions between HIV-1 and the cell-autonomous innate immune system. Cell Host Microbe. 2014; 16(1):10-8.

13. [Internet] The Joint United Nations Programme on HIV/AIDS (UNAIDS). https://www.unaids.org/en. 2020 (accessed November 2020).

14. Montoya WR, Anaya JM. Inmunología de Rojas, sixteenth ed. Corporación para Investigaciones Biológicas. 2012.

15. [Internet] Grupo de Estudio del SIDA-SEIMC (GESIDA). http://gesida-seimc. org/. 2020 (accessed November 2020).

16. Trono D, Van Lint C, Rouzioux C, Verdin E, Barré-Sinoussi F, Chun TW, et al. HIV persistence and the prospect of long-term drug-free remissions for HIV-infected individuals. Science. 2010; 329(5988):174-80.

17. Song $\mathrm{Z}, \mathrm{Xu} \mathrm{Y}, \mathrm{Bao} \mathrm{L}, \mathrm{Zhang} \mathrm{L}, \mathrm{Yu} \mathrm{P}, \mathrm{Qu} \mathrm{Y}$, et al. From SARS to MERS, thrusting coronaviruses into the spotlight. Viruses. 2019; 11(1).

18. Cui J, Li F, Shi ZL. Origin and evolution of pathogenic coronaviruses. Nat Rev Microbiol. 2019; 17(3):181-92.

19. Hamming I, Timens W, Bulthuis MLC, Lely AT, Navis GJ, van Goor H. Tissue distribution of ACE2 protein, the functional receptor for SARS coronavirus. A first step in understanding SARS pathogenesis. J Pathol. 2004; 203(2):631-7.

20. Tortorici MA, Veesler D. Structural insights into coronavirus entry. 1st ed. Vol. 105, Advances in Virus Research. Elsevier Inc. 2019; p:93-116.

21. Zhang YZ, Holmes EC. A Genomic Perspective on the Origin and Emergence of SARS-CoV-2. Cell. 2020; 181(2):223-7.

22. Xia S, Zhu Y, Liu M, Lan Q, Xu W, Wu Y, et al. Fusion mechanism of 2019-nCoV and fusion inhibitors targeting HR1 domain in spike protein. Cell Mol Immunol. 2020; (February):3-5.

23. Yu F, Du L, Ojcius DM, Pan C, Jiang S. Measures for diagnosing and treating infections by a novel coronavirus responsible for a pneumonia outbreak originating in Wuhan, China. Microbes Infect. 2020; 22(2):74-9.

24. de Wilde AH, Snijder EJ, Kikkert M, van Hemert MJ. Host Factors in Coronavirus Replication. Roles of Host Gene and Non-coding RNA Expression in Virus Infection, Springer, Cham. 2017; p:1-42.

25. Sawicki SG, Sawicki DL. Coronavirus transcription: A perspective. Curr Top Microbiol Immunol. 2005; 287:31-55.

26. Hussain S, Pan J, Chen Y, Yang Y, Xu J, Peng Y, et al. Identification of Novel Subgenomic RNAs and Noncanonical Transcription Initiation Signals of Severe Acute Respiratory Syndrome Coronavirus. J Virol. 2005; 79(9):5288-95.

27. Perrier A, Bonnin A, Desmarets L, Danneels A, Goffard A, Rouillé Y, et al. The C-terminal domain of the MERS coronavirusMprotein contains a trans-Golgi network localization signal. J Biol Chem. 2019; 294(39):14406-21.

28. Lan L, Xu D, Ye G, Xia C, Wang S, Li Y, et al. Positive RT-PCR Test Results in Patients Recovered from COVID-19. JAMA - J Am Med Assoc. 2020; 323(15):1502-3.

29. Munster V, Feldmann F, Williamson B, Doremalen $\mathrm{N}$ van, Lizzette Perez-Perez, Schultz J, et al. Respiratory disease and virus shedding in rhesus macaques inoculated with SARS-CoV-2. bioRxiv. 2020; 2020.03.21.001628.

30. Bao L, Deng W, Huang B, Gao H, Liu J, Ren L, et al. The Pathogenicity of SARS-CoV-2 in hACE2 Transgenic Mice. bioRxiv. 2020; 2020.02.07.939389.

31. Lou B, Li T, Zheng S, Su Y, Li Z, Liu W, et al. Serology characteristics of SARS-CoV-2 infection since the exposure and post symptoms onset. medRxiv. 2020; 2020.03.23.20041707.

32. Roback JD, Guarner J. Convalescent Plasma to Treat COVID-19: Possibilities and Challenges. JAMA - J Am Med Assoc. 2020; 323:1561-1562.

33. Ahn DG, Shin HJ, Kim MH, Lee S, Kim HS, Myoung J, et al. Current Status of Epidemiology, Diagnosis, Therapeutics, and Vaccines for Novel Coronavirus Disease 2019 (COVID-19). J Microbiol Biotechnol. 2020; 30:313-324.

34. Li LQ, Huang T, Wang YQ, Wang ZP, Liang Y, Huang TB, et al. COVID-19 patients' clinical characteristics, discharge rate, and fatality rate of meta-analysis. J Med Virol. 2020; 92(6):577-83.

35. Feng Z, Li O, Zhang Y. Novel Coronavirus Pneumonia Emergency Response Epidemiology, The epidemiological characteristics of an outbreak of 2019 novel coronavirus diseases (COVID-19) in China. Zhonghua Liu Xing Bing Xue Za Zhi. 2020; 41:145-151.

36. Jin $\mathrm{Y}$, Yang $\mathrm{H}$, Ji W, Wu W, Chen S, Zhang W, et al. Virology, epidemiology, pathogenesis, and control of covid-19. Viruses. 2020; 12(4):1-17.

37. [Internet] Ministry of Health, Spain. Enfermedad por nuevo coronavirus, COVID-19. https://www.mscbs.gob.es/profesionales/saludPublica/ccayes/ alertasActual/nCov-China/home.htm. 2020 (accessed November 2020).

38. Chih Cheng L, Tzu Ping S, Wen Chien K, Hung Jen T, Po Ren H. Severe acute respiratory syndrome coronavirus 2 (SARS-CoV-2) and coronavirus disease-2019 (COVID-19): The epidemic and the challenges. Int J Antimicrob Agents. 2020; 55(January):1-9.

39. Lake MA. What we know so far: COVID-19 current clinical knowledge and research. Clin Med J R Coll Physicians London. 2020; 20(2):124-7.

40. Cao B, Wang Y, Wen D, Liu W, Wang J, Fan G, et al. A trial of lopinavir-ritonavir in adults hospitalized with severe covid-19. N Engl J Med. 2020; 382(19):1787-99.

41. Wang Y, Zhang D, Du G, Du R, Zhao J, Jin Y, et al. Remdesivir in adults with severe COVID-19: a randomised, double-blind, placebo-controlled, multicentre trial. Lancet. 2020; 395(10236):1569-78. 
42. Beigel JH, Tomashek KM, Dodd LE, Mehta AK, Zingman BS, Kalil AC, et al. Remdesivir for the Treatment of Covid-19 - Preliminary Report. N Engl J Med. 2020; p:1-12.

43. Fadel R, Morrison AR, Pharm D, Vahia A, Smith ZR, Pharm D, et al. Early Short Course Corticosteroids in Hospitalized Patients with COVID-19. Clin Infect Dis. 2020; https://doi.org/10.1093/cid/ciaa601.

44. Callaway E. The race for Coronavirus vaccines. Nature. 2020; 580:576-7.

45. Carding S, Verbeke K, Vipond DT, Corfe BM, Owen LJ. Dysbiosis of the gut microbiota in disease. Microb Ecol Heal Dis. 2015; 26(0)

46. Borges ÁH, O'Connor JL, Phillips AN, Neaton JD, Grund B, Neuhaus J, et al. Interleukin 6 Is a Stronger Predictor of Clinical Events Than High-Sensitivity C-Reactive Protein or D-Dimer during HIV Infection. J Infect Dis. 2016; 214(3):408-16.

47. Soy M, Keser G, Atagündüz P, Tabak F, Atagündüz I, Kayhan S. Cytokine storm in COVID-19: pathogenesis and overview of anti-inflammatory agents used in treatment. Clin Rheumatol. 2020; 39(7):2085-94.

48. Liu J, Zheng $\mathrm{X}$, Tong $\mathrm{Q}, \mathrm{Li} \mathrm{W}$, Wang $\mathrm{B}$, Sutter $\mathrm{K}$, et al. Overlapping and discrete aspects of the pathology and pathogenesis of the emerging human pathogenic coronaviruses SARS-CoV, MERS-CoV, and 2019-nCoV. J Med Virol. 2020; 92(5):491-4.

49. Moccia F, Gerbino A, Lionetti V, Miragoli M, Munaron LM, Pagliaro P, et al. COVID-19-associated cardiovascular morbidity in older adults: a position paper from the Italian Society of Cardiovascular Researches. GeroScience. 2020; 42(4):1021-49.

50. Tincati C, Douek DC, Marchetti G. Gut barrier structure, mucosal immunity and intestinal microbiota in the pathogenesis and treatment of HIV infection. AIDS Res Ther. 2016; 13(1):1-11.

51. Vujkovic-Cvijin I, Sortino O, Verheij E, Sklar J, Wit FW, Kootstra NA, et al. HIV-associated gut dysbiosis is independent of sexual practice and correlates with noncommunicable diseases. Nat Commun. 2020; 11(1)

52. Dinh DM, Volpe GE, Duffalo C, Bhalchandra S, Tai AK, Kane A V, et al. Intestinal Microbiota, microbial translocation, and systemic inflammation in chronic HIV infection. J Infect Dis. 2015; 211(1):19-27.

53. Noguera-Julian M, Rocafort $M$, Guillén $Y$, Rivera J, Casadellà M, Nowak $P$, et al. Gut Microbiota Linked to Sexual Preference and HIV Infection. EBioMedicine. 2016; 5:135-46.

54. Vujkovic-Cvijin I, Dunham RM, Iwai S, Maher MC, Albright RG, Broadhurst MJ, et al. Dysbiosis of the gut microbiota is associated with HIV disease progression and tryptophan catabolism. Sci Transl Med. 2013; 5(193).

55. Monaco CL, Gootenberg DB, Zhao G, Handley SA, Musie S, Lim ES, et al. Altered Virome and Bacterial Microbiome in Human Immuni. Cell Host Microbe. 2017; 19(3):311-22.

56. Lozupone CA, Li M, Campbell TB, Flores SC, Linderman D, Gebert MJ, et al. Alterations in the gut microbiota associated with HIV-1 infection. Cell Host Microbe. 2013; 14(3):329-39.

57. Dillon SM, Lee EJ, Kotter C V., Austin GL, Dong Z, Hecht DK, et al. An altered intestinal mucosal microbiome in HIV-1 infection is associated with mucosal and systemic immune activation and endotoxemia. Mucosal Immunol. 2014; 7(4):983-94.

58. Mutlu EA, Keshavarzian A, Losurdo J, Swanson G, Siewe B, Forsyth C, et al. A Compositional Look at the Human Gastrointestinal Microbiome and Immune Activation Parameters in HIV Infected Subjects. PLoS Pathog. 2014; 10(2).

59. Vázquez-Castellanos JF, Serrano-Villar S, Latorre A, Artacho A, Ferrús ML, Madrid N, et al. Altered metabolism of gut microbiota contributes to chronic immune activation in HIV-infected individuals. Mucosal Immunol. 2015; 8(4):760-72.

60. Ling Z, Jin C, Xie T, Cheng Y, Li L, Wu N. Alterations in the Fecal Microbiota of Patients with HIV-1 Infection: An Observational Study in A Chinese Population. Sci Rep. 2016; 6(July):30673.

61. Smith PM, Howitt MR, Panikov N, Michaud M, Gallini CA, Bohlooly-Y M, et al. The microbial metabolites, short-chain fatty acids, regulate colonic Treg cell homeostasis. Science. 2013; 341(6145):569-73.

62. Vesterbacka J, Rivera J, Noyan K, Parera M, Neogi U, Calle M, et al. Richer gut microbiota with distinct metabolic profile in HIV infected Elite Controllers. Sci Rep. 2017; 7(1):1-13.

63. Buckheit RW, Salgado M, Martins KO, Blankson JN. The implications of viral reservoirs on the elite control of HIV-1 infection. Cell Mol Life Sci. 2013; 70(6):1009-19.

64. Papayannopoulos V. Neutrophil extracellular traps in immunity and disease. Nat Rev Immunol. 2018; 18(2):134-47.

65. Brinkmann V, Reichard U, Goosmann C, Fauler B, Uhlemann Y, Weiss DS, et al. Neutrophil Extracellular Traps Kill Bacteria. Science (80- ). 2004; 303(5663):1532-5.

66. Saitoh T, Komano J, Saitoh Y, Misawa T, Takahama M, Kozaki T, et al. Neutrophil extracellular traps mediate a host defense response to human immunodeficiency virus-1. Cell Host Microbe. 2012; 12(1):109-16.

67. Soehnlein O, Steffens S, Hidalgo A, Weber C. Neutrophils as protagonists and targets in chronic inflammation. Nat Rev Immunol. 2017; 17(4):248-61.

68. Mozzini C, Girelli D. The role of Neutrophil Extracellular Traps in Covid-19: Only an hypothesis or a potential new field of research? Thromb Res. 2020; 191(April):26-7. 